Abstracta Iranica Abstracta Iranica

Revue bibliographique pour le domaine irano-aryen

Volume 22 | 2001

Comptes rendus des publications de 1999

\title{
La miniature persane. Les couleurs de la lumière: le miroir et le jardin. Paris, Farrago, 1999, 61 p., facsim.
}

\section{Charles-Henri de Fouchécour}

\section{(2) OpenEdition}

1 Journals

Édition électronique

URL : http://journals.openedition.org/abstractairanica/36698

DOI : 10.4000/abstractairanica.36698

ISSN : 1961-960X

\section{Éditeur :}

CNRS (UMR 7528 Mondes iraniens et indiens), Éditions de l'IFRI

\section{Édition imprimée}

Date de publication : 15 mai 2001

ISSN : 0240-8910

\section{Référence électronique}

Charles-Henri de Fouchécour, "La miniature persane. Les couleurs de la lumière : le miroir et le jardin.

Paris, Farrago, 1999, 61 p., facsim. », Abstracta Iranica [En ligne], Volume 22 | 2001, document 298, mis en ligne le 16 février 2010, consulté le 13 octobre 2020. URL : http://journals.openedition.org/ abstractairanica/36698; DOI : https://doi.org/10.4000/abstractairanica.36698

Ce document a été généré automatiquement le 13 octobre 2020.

Tous droits réservés 


\title{
La miniature persane. Les couleurs de la lumière : le miroir et le jardin. Paris, Farrago, 1999, 61 p., facsim.
}

\author{
Charles-Henri de Fouchécour
}

La miniature persane méritait bien ces pages denses, où l'auteur en trace rapidement l'histoire, indique ses grands monuments, esquisse des comparaisons avec d'autres formes de peinture, celles de l'Occident spécialement, celle de Chine aussi. Il montre comment, sans ses couleurs de lumière, la miniature persane n'opérerait pas son alchimie, la transsubstantiation des choses. L'une des notions qui courent dans ce petit volume est celle de l'ornement. Oleg Grabar nous y avait habitués et a promis des développements sur la découverte de ce qui est, à son sens, un trait de base de tout l'art islamique. Ce livre suggestif dépasse les descriptions techniques habituelles pour aller à une compréhension plus poussée de ce qui fait le propre de la miniature persane. Mais il n'évite pas des raccourcis réducteurs sur des faits de la miniature que l'on ne peut réduire à rien. Quand il écrit : « L'ornement consiste en la forme pure : il ne renvoie ni à un objet, ni à une signification» (p. 37), on reste surpris de pareille simplification. Les grandes scènes humaines que figurent la miniature sont des sortes de «textes de lumière » issus d'une compréhension visuelle qui n'a d'égale que la poésie. On espère une suite à ces pages qui font réfléchir.

\section{INDEX}

Thèmes : 5.1. Monde iranophone 


\section{AUTEURS}

\section{CHARLES-HENRI DE FOUCHÉCOUR}

Sorbonne Nouvelle - Paris III 